\title{
Seasonal Changes and Spatial Variation of Reactive Nitrogen in Sultanpur Lake, Haryana, India \\ Priyanka Verma ${ }^{1}$, Pamposh ${ }^{2}$
}

${ }^{1}$ University School of Environment Management, Guru Gobind Singh Indraprastha University, New Delhi, Delhi, India

${ }^{2}$ University School of Environment Management, Guru Gobind Singh Indraprastha University, New Delhi, Delhi, India

\begin{tabular}{|c|c|}
\hline & ABSTRACT \\
\hline Article Info & Sultanpur Lake is a rain-fed seasonal water body that dries up in summer. It is a \\
\hline Volume 8 , Issue 2 & haven for avian fauna and has been attracting birds for the past 100 years. This \\
\hline Page Number : 477-488 & study examined the spatio-temporal variability of reactive nitrogen species in \\
\hline & Sultanpur Lake using the geostatistical module of ArcGIS which is based on the \\
\hline Publication Issue & monitoring data collected from 2017 to 2019. Seasonal concentration and \\
\hline March-April-2021 & $\begin{array}{l}\text { spatial distribution of reactive nitrogen (nitrate, nitrite, ammonia, organic } \\
\text { nitrogen, and total Kjeldahl nitrogen) in Sultanpur Lake's surface water were }\end{array}$ \\
\hline Article History & assessed at eight points. Seasonally, the concentration of reactive nitrogenous \\
\hline Accepted : 15 April 2021 & species was found to be maximum in winter followed by monsoon and summer. \\
\hline \multirow[t]{9}{*}{ Published : 20 April 2021} & Spatially, the concentration varied at different points. Points $1,2,3$, and 4 \\
\hline & (right side) had less concentration of reactive nitrogen as compared to Points 5 , \\
\hline & 6,7 , and 8 (left side). The seasonal variation is found to be associated with \\
\hline & extreme climatic conditions. This study highlights the areas of the lake which \\
\hline & are under anthropogenic stresses such as agricultural runoff, manual water \\
\hline & pumping, livestock from the nearby fields. This study will help to frame better \\
\hline & management practices for this important wetland which harbors avian fauna \\
\hline & during the winter season. \\
\hline & $\begin{array}{l}\text { Keywords: ArcGIS, reactive nitrogen, spatial distribution, Sultanpur Lake, } \\
\text { temporal variation }\end{array}$ \\
\hline
\end{tabular}

\section{INTRODUCTION}

During the last few centuries, the global nitrogen cycle is highly altered due to human activities. Excess use of fertilizers, fossil fuel combustion, severe change in land use land cover pattern has intensely affected the movement of nitrogen into the freshwater system
(Jansson et al., 1994; Vitousek et al., 1997; Moffat, 1998). Elevated concentration of nitrogen, surges the risk of eutrophication in the aquatic ecosystem (Moffat, 1998). Wetlands has an ability to retain a high proportion of nitrogen followed by lakes and then rivers (Saunders and Kalff, 2001). Over a wide range of spatial and temporal scales, wetlands are in 
constant instability due to natural and anthropogenic sources. They are highly dynamic systems constituting lakes, marshes, peatlands, floodplains, and mangroves, which are constantly or periodically submerged under flowing or still fresh, salty, or brackish water (Smith et al., 1995; Syphard and Garcia, 2001). For hundreds of years, Sultanpur Lake has been attracting bird species from around the world. Wetlands being guardians of water birds attract many migratory and resident bird species due to their high nutritional value and productivity (Weller, 1999; Stewart, 2001; Manikannan et al., 2012; Siva and Neelanarayan, 2017). In 1969, the conference of the International Union of Conservation of Nature and Natural Resources (IUCN), in New Delhi identified the potential of this wetland which was serving as a harbor for many migratory and resident species. On July 5, 1991, the bird sanctuary was notified as a National park under section 35 of the Wildlife Protection Act 1972 (Kalpavriksh, 1994). This shallow lake is fed by overflowing agricultural fields nearby and receives water from the Gurugram canal of river Yamuna (Banerjee and Pal 2017). The water level in the lake remains maximum during monsoon and winter, and dry condition prevails during the summer months when small pools of water are formed of about $30 \mathrm{~cm}$ depth. Seasonal aquatic vegetation and open grassland, and human-made mounds of grasses and mud prove to be an excellent habitat for different species of birds for resting and roosting (Banerjee and Pal, 2017).

The chemical composition of surface water varies greatly depending on the type and use of the surrounding area. Nutrients, primarily in the form of nitrogen and phosphorus, are the main components that cross rivers and lakes in small agricultural catchments (Koc and Solarski, 2006; Czyżyk and Strzelczyk, 2008; Sapek, 2008). The land use assessment indicates that the local villagers graze their livestock within the sanctuary premises and collect aquatic vegetation for thatch and fodder. There is a high level of disturbances from the tourist activities, especially when the water levels are low and the birds are concentrated within a small area (Singh et al., 2017). Excavation of the sand is done for nearby lime and brick industries. Land-use modifications in the catchment such as expanding settlements, construction of farmhouses, and other buildings have obstructed the natural flow into the lake, thereby causing the drying of the lake. Due to scanty rainfall, artificial pumping of water from the river Yamuna is performed, which causes the entrance of African Catfish (Clarias gareipinus) along with water, thereby damaging the ecosystem (Banerjee and Pal, 2017). It is an omnivorous predator that feeds on the native flora and fishes, which hamper the natural availability of food for birds and animals.

The objective of the study is to assess spatial and temporal variation of reactive nitrogen concentration in the water column and estimate variation in concentration seasonally, which will help highlight the part of the lake that is under anthropogenic stress to attain better management.

\section{METHODS AND MATERIAL}

\section{Study area}

Sultanpur National Park (28 $28^{\prime}$ N Latitude and 76053' $\mathrm{E}$ Longitudes) is located in a predominantly agricultural landscape (Fig. 1). It is situated in the Gurugram district of Haryana in village Sadhrana. It covers an area of 13,727 ha with a core area of 143 ha containing the main lake area of approximately 96 ha. (Islam and Rahmani, 2004; Birdlife international, 2019). This lake is a seasonal freshwater marshy natural depression with irregular margins contained in a salt pane. The water level fluctuates throughout the year. It is a large area of seasonally flooded sedges that extends from the northern part to the main lake area (Kalpavriksh, 1994). This shallow lake is fed by overflowing agricultural fields nearby and receives water from the Gurugram canal of river Yamuna (Banerjee and Pal, 2017). 


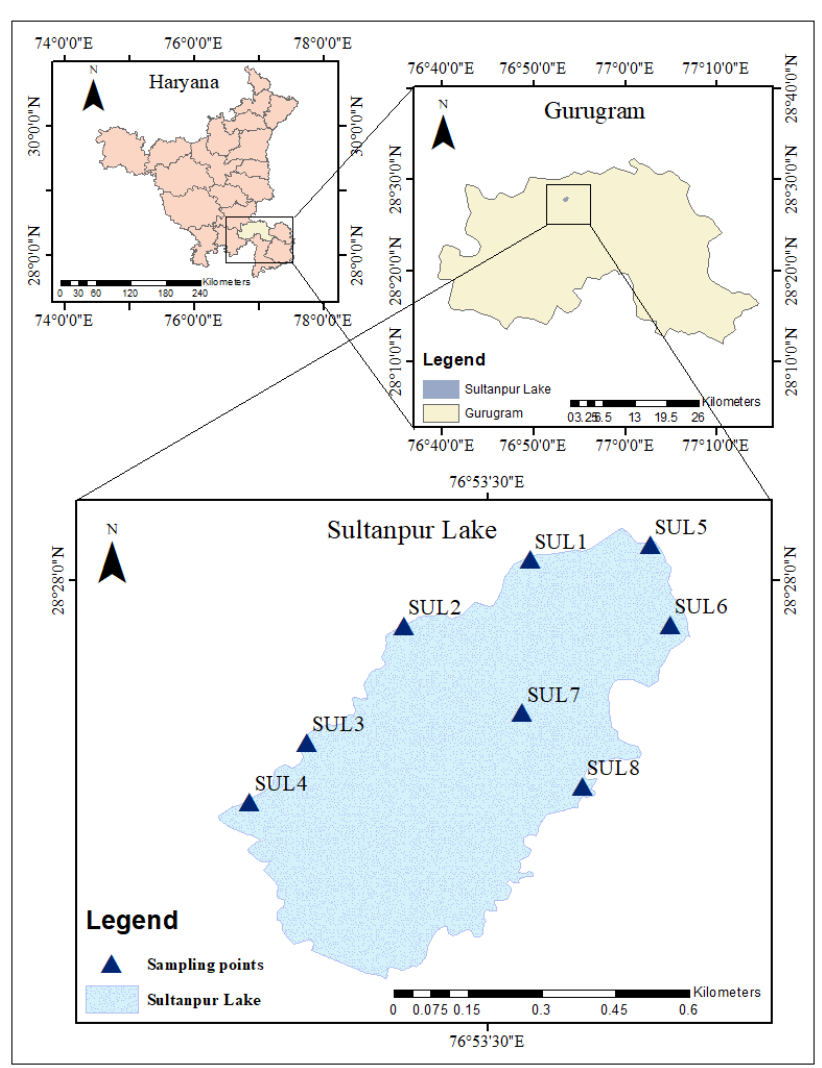

Fig 1: Sampling points in Sultanpur Lake

\section{Sample collection}

The water samples were collected from Sultanpur Lake seasonally (summer, monsoon, and winter) from 2017 to 2019. The position of the sampling points was located using GPS (Gramin eTrex 20x). The distribution of the sampling points is shown in Fig.1. The water sampling points were located radially on the periphery of the lake. There were 8 sampling points along the lake. Three replicates were collected from each sampling point.

\section{Experimental and analytical methods}

The water samples were collected in polypropylene plastic bottles and were stored at a constant temperature in an icebox. The samples were transported to the laboratory for further processing. The samples were filtered with the help of filtration assembly using Grade 1 Whatman paper. The samples were analysed for nitrate $\left(\mathrm{NO}_{3}\right)$ by $\mathrm{UV}$ spectrophotometry, nitrite $\left(\mathrm{NO}_{2}\right)$ by colorimetric method, ammonia $\left(\mathrm{NH}_{3}\right)$ by distillation method, Total Kjeldahl nitrogen (TKN) and Organic nitrogen (OrgN) using total Kjeldahl method, and Total nitrogen (TN) was calculated using the sum of Kjeldahl nitrogen, nitrate, and nitrite (APHA, 1999; CPCB, 2011).

\section{Spatial interpolation mapping in Geographic information system}

Using the spatial analyst tool of ArcGIS software 10.3.1, a spatial distribution for the point data collected from the location was interpolated to create thematic maps that present spatio-temporal dynamics of the reactive nitrogen forms within the surface boundaries. The inverse distance weighted (IDW) interpolation has been applied in estimating the values between measured data points. In this technique, the computation of weighted values of the unsampled point is inversely proportional to the squared distance between observed point data and point of unsampled location (Burrough and Mc Donnell, 1998)

\section{III.RESULTS AND DISCUSSION}

Nitrogen is an essential resource for the proliferation and growth of aquatic plants in the lake. Most of the time, it is referred to as an important factor affecting the lake's primary productivity and environmental quality. (Lehtorantan et al., 1997; Devine and Vanni, 2002; Li et al., 2007; Huang et al., 2010; DongNan et al., 2011). It enters into the system in various forms that may be organic and inorganic. Several factors affect the concentration of different forms of nitrogen, including proximity to point and non-point sources, the influence of groundwater baseflow discharging into the water, area, type of wetland, and other natural and anthropogenic factors.

Fig. 2 and 3 graphically represents the spatiotemporal comparison between different reactive nitrogen (TKN, $\mathrm{NH}_{3}, \mathrm{OrgN}, \mathrm{NO}_{2}^{-}, \mathrm{NO}_{3}{ }^{-}$and $\mathrm{TN}$ ) concentration.

\section{Ammonia}

In 2017-18, the range of ammonia was 2.39 to 8.29 $\mathrm{mg} / \mathrm{l}, 2.19$ to $13.83 \mathrm{mg} / \mathrm{l}$, and 4.43 to $8.92 \mathrm{mg} / \mathrm{l}$ in 
summer, monsoon, and winter respectively (Fig. 2).

are $4.70 \mathrm{mg} / 1,5.81 \mathrm{mg} / 1,6.49 \mathrm{mg} / \mathrm{l}$ respectively.

The summer, monsoon and winter average values

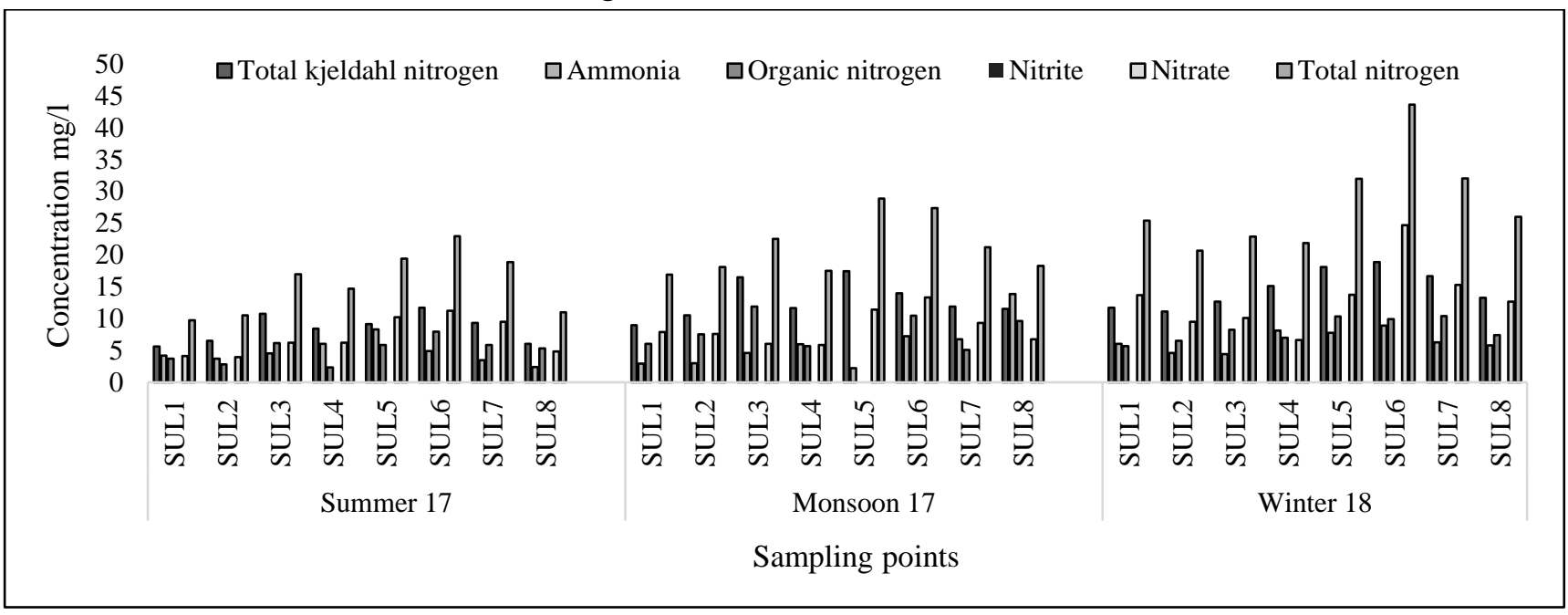

Fig 2: Seasonal change in the concentration of reactive nitrogen forms at different sampling location in Sultanpur Lake in 2017-18

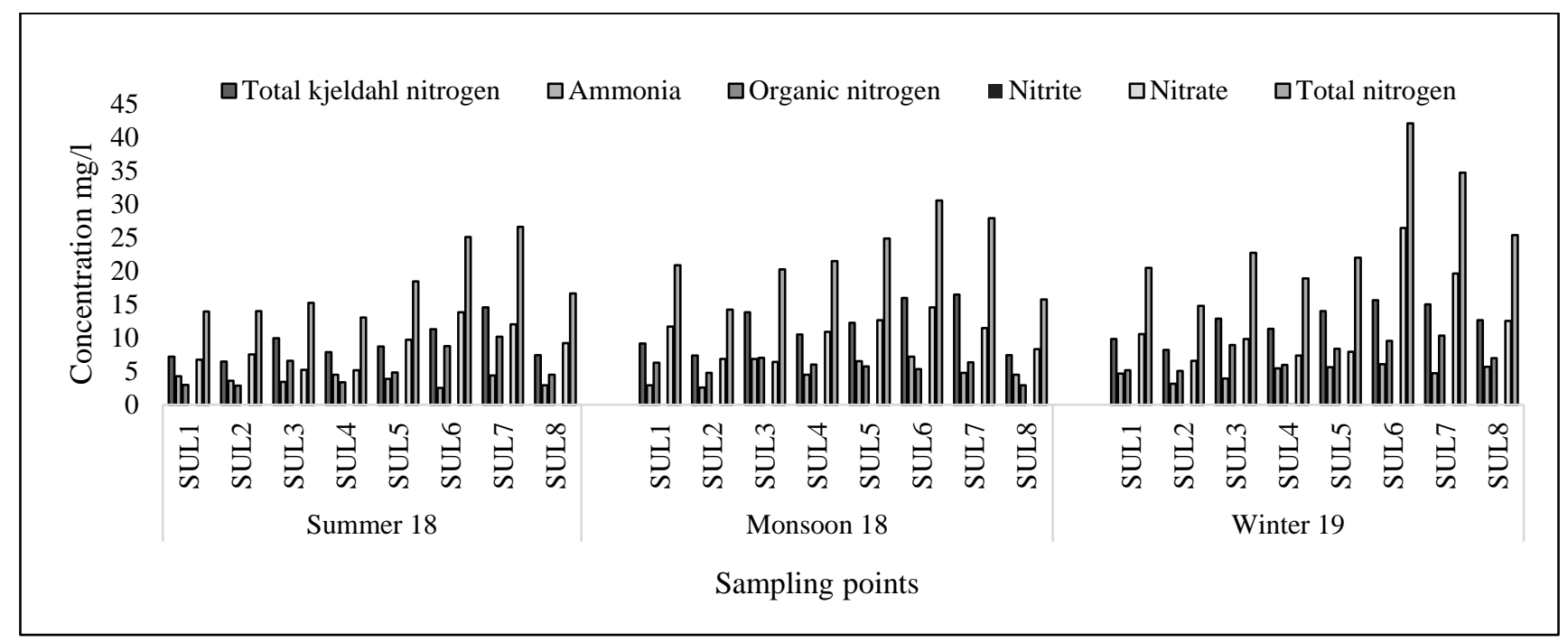

Fig 3: Seasonal change in the concentration of reactive nitrogen forms at different sampling location in Sultanpur Lake in 2018-19

The IDW maps show the spatial distribution of ammonia in different seasons. The change in colour shows the minimum and maximum concentration at different sampling points which may be affected by different factors. The red colour denotes the highest concentration at sampling points SUL 5, 6, and 8 due to the return flow from agricultural fields and the blue colour denotes the lowest concentration. Waste from agriculture and aquaculture is rich in nitrogenous compounds (Krithika et al., 2008). The lowest concentration was noted at SUL 2 because not much of the activity occurs in that area except birding trails (Fig. 4 a, b, c). Seasonally the maximum concentration of ammonia was observed in monsoon (13.83 $\mathrm{mg} / \mathrm{l})$ followed by winter $(8.92 \mathrm{mg} / \mathrm{l})$ and summer $(8.3 \mathrm{mg} / \mathrm{l})$. Due to the high growth of planktons and aquatic plants, which are mostly populating during summer season, the lowest concentration was observed (Abdel-Moati et al., 1990; Okbah and Hussein, 2006). 


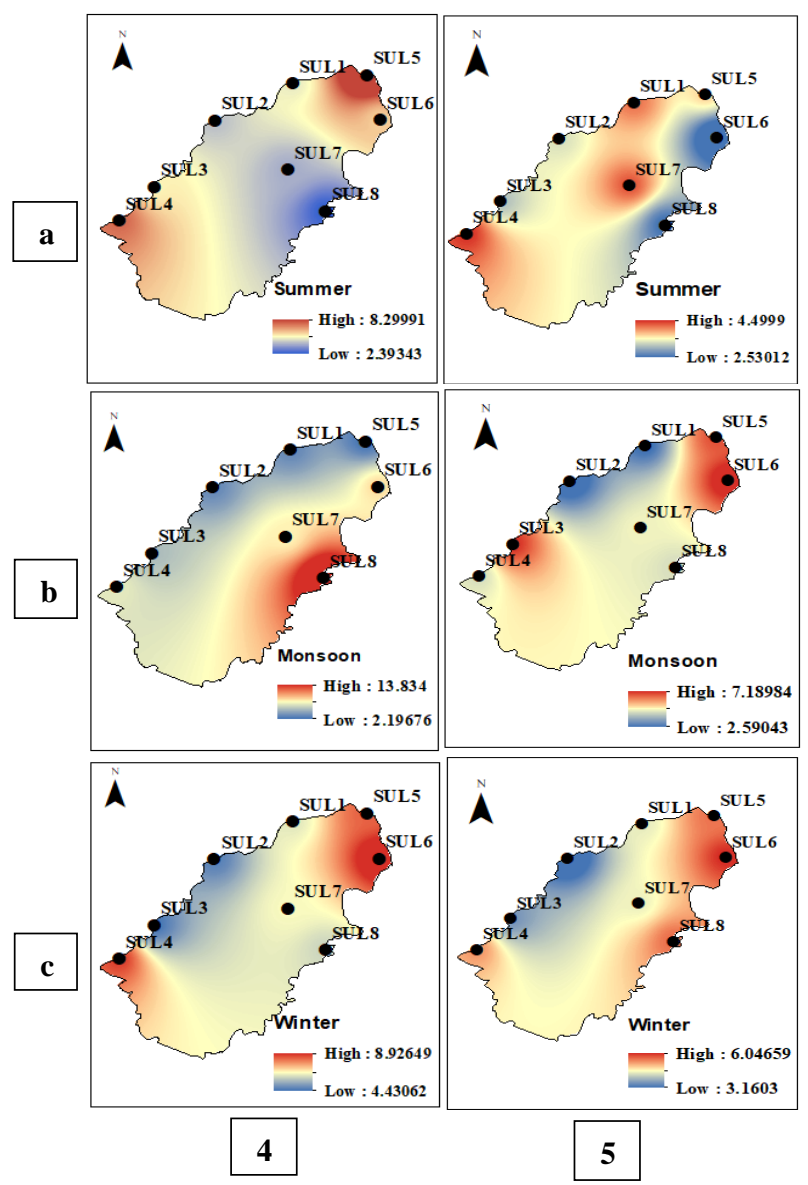

Fig 4a, b, c: shows spatial and seasonal variation of $\mathrm{NH}_{3}$ in 2017-18

$5 a, b, c$ : shows spatial and seasonal variation of $\mathrm{NH}_{3}$ in 2018-19

In 2018-19, the range of ammonia is 2.53 to $4.49 \mathrm{mg} / \mathrm{l}$, 2.59 to $7.18 \mathrm{mg} / \mathrm{l}$, and 3.16 to $6.04 \mathrm{mg} / \mathrm{l}$ in summer, monsoon, and winter respectively (Fig. 3). The summer, monsoon, and winter average values are 3.68 $\mathrm{mg} / \mathrm{l}, 4.97 \mathrm{mg} / \mathrm{l}, 4.89 \mathrm{mg} / \mathrm{l}$ respectively. The highest concentration was observed at sampling points SUL 4 and 6 and lowest at SUL 2 (Fig. 5 a, b, c). Seasonally, the maximum concentration was observed in monsoon $(7.18 \mathrm{mg} / \mathrm{l})$ followed by winter $(6.04 \mathrm{mg} / \mathrm{l})$ and summer $(4.05 \mathrm{mg} / \mathrm{l})$. The yearly average shows that the concentration of ammonia was found to be higher in 2017-18 than in 2018-19.

\section{Nitrate}

Oxidation of ammonia forms nitrate as its final product (Meng et al., 2018). In 2017-18, the range of nitrate was 3.95 to $11.22 \mathrm{mg} / \mathrm{l}, 5.84$ to $13.35 \mathrm{mg} / \mathrm{l}$ and
6.63 to $24.66 \mathrm{mg} / \mathrm{l}$ in summer, monsoon and winter respectively. The summer, monsoon, and winter average values are $7.04 \mathrm{mg} / 1,8.53 \mathrm{mg} / \mathrm{l}, 13.28 \mathrm{mg} / \mathrm{l}$ respectively. The highest concentration was observed at sampling points SUL 6, which may be primarily due to groundwater pumping and agricultural return flow. When the waterbody originates or is surrounded by an agricultural field, nitrate concentration is more than organic nitrogen (Araújo, 2011; Wall, 2013). Seasonally the maximum concentration was observed in winter $(24.66 \mathrm{mg} / \mathrm{l})$ followed by monsoon $(13.35 \mathrm{mg} / \mathrm{l})$ and summer $(11.22$ mg/l) (Fig. 6 a, b, c).

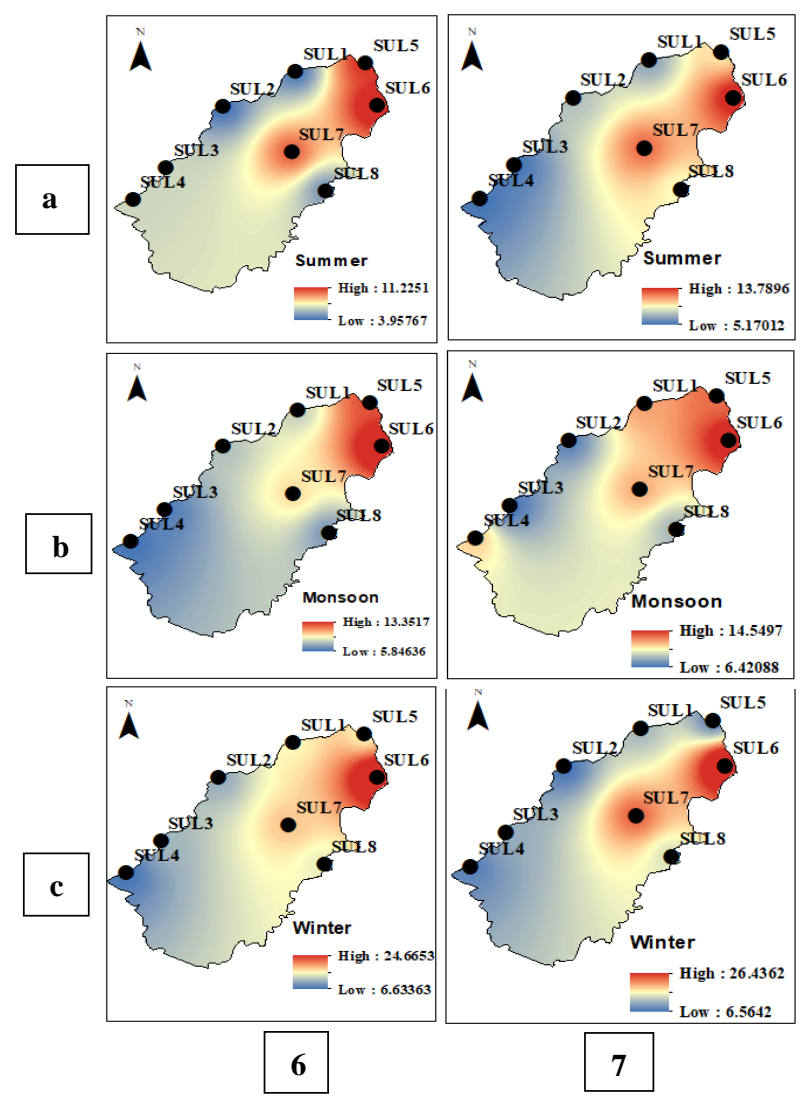

Fig 6a, b, c: shows spatial and seasonal variation of nitrate in 2017-18

7a, b, c: shows spatial and seasonal variation of nitrate in 2018-19

In $2018-19$, the range of nitrate was 5.17 to $13.78 \mathrm{mg} / \mathrm{l}$, 6.41 to $14.55 \mathrm{mg} / \mathrm{l}$, and 6.56 to $26.43 \mathrm{mg} / \mathrm{l}$ in summer, monsoon, and winter respectively (Fig. 3). The summer, monsoon, and winter average values are 8.67 
$\mathrm{mg} / \mathrm{l}, 10.34 \mathrm{mg} / \mathrm{l}, 12.60 \mathrm{mg} / \mathrm{l}$ respectively. The highest concentration was observed at sampling point SUL 6 and lowest at points 2, 3, and 4 in winter, monsoon, and summer, respectively (Fig. 7 a, b, c). Overall concentration increased in 2018-19 as compared with 2017-18 due to some dredging activities taking place near SUL 5 and 6 which led to the disturbance of the bottom sediment allowing it to mix with water. The levels of nitrate in water are less than one ppm usually. The presence of higher levels means that the water is polluted. Fertilizers, animal wastes, septic tanks, municipal sewage treatment systems, and decaying plant debris are common sources of nitrate pollution (Rajamohan and Elango, 2005; Prasanna et al., 2011; Brindha et al., 2012; Priyadarshni et al., 2017). Seasonally the maximum concentration was observed in winter $(24.66 \mathrm{mg} / \mathrm{l})$, followed by monsoon (13.35 mg/l) and summer (11.22 mg/l).

\section{Total kjeldahl nitrogen}

Total Kjeldahl nitrogen includes organic nitrogen and ammonia. Typically, the organic-N fraction of TKN in surface waters is much higher than the ammonia plus ammonium-N fraction (Wall, 2013). In 2017-18, the range of total Kjeldahl nitrogen was 5.60 to 11.69 $\mathrm{mg} / \mathrm{l}, 8.96$ to $17.45 \mathrm{mg} / \mathrm{l}$, and 11.12 to $18.85 \mathrm{mg} / \mathrm{l}$ in summer, monsoon, and winter, respectively (Fig. 2). The average value was $8.4 \mathrm{mg} / 1,12.80 \mathrm{mg} / \mathrm{l}$, and 14.69 $\mathrm{mg} / \mathrm{l}$ in summer, monsoon, and winter respectively. Seasonally the concentration of total Kjeldahl nitrogen was maximum in winter (18.6 mg/l) followed by monsoon $(17.45 \mathrm{mg} / \mathrm{l})$ and summer $(11.7$ $\mathrm{mg} / \mathrm{l}$ ). The maximum concentration was observed due to fecal matter from migratory that visit the water body in the winter season. Nutrients derived from fecal can enrich surface water and lead to eutrophication, which causes lakes to mature more rapidly (Fleming and Fraser, 2001). The highest concentration was observed at sampling point SUL 6 and lowest at SUL 1 in all the seasons (Fig. 8 a, b, c). In 2018-19, the total Kjeldahl nitrogen range was 6.46 to $14.52 \mathrm{mg} / \mathrm{l}, 7.37$ to $16.43 \mathrm{mg} / \mathrm{l}$, and 8.19 to 15.61 $\mathrm{mg} / \mathrm{l}$ in summer monsoon and winter, respectively (Fig. 3). The average value was $9.17 \mathrm{mg} / \mathrm{l}$ in summer followed by $11.61 \mathrm{mg} / \mathrm{l}$ in monsoon and $12.43 \mathrm{mg} / \mathrm{l}$ in winter. The highest concentration was observed at sampling point SUL 7 and lowest at SUL 2 for all the seasons (Fig. 9 a, b, c). Mostly the birds flock around SUL 7 that may be the reason for high concentrations. Seasonally the concentration of total Kjeldahl nitrogen was more or less similar in all the seasons. The yearly average shows that the concentration of total Kjeldahl nitrogen was higher in 2018-19 as compared to 2017-18.

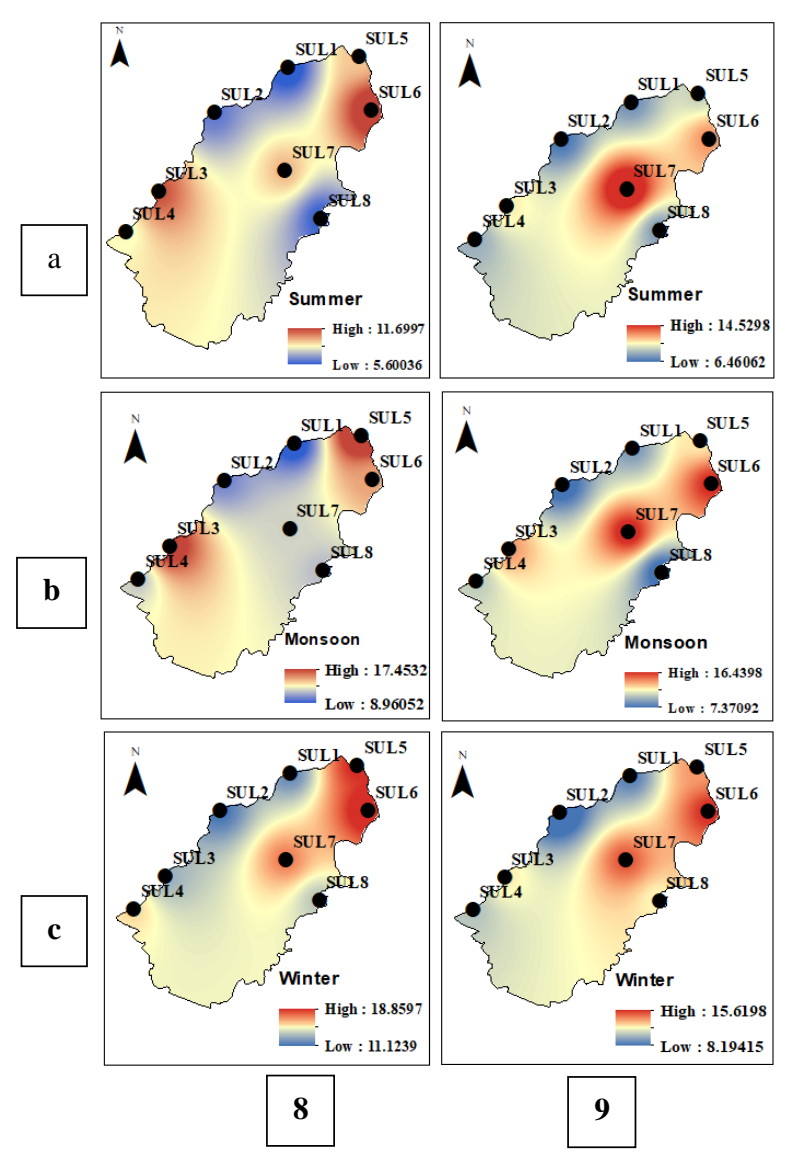

Fig 8a, b, c: shows spatial and seasonal variation of total Kjeldahl nitrogen in 2017-18

9a, b, c: shows spatial and seasonal variation of total Kjeldahl nitrogen in 2018-19

\section{Total nitrogen}

In 2017-18, The range of total nitrogen was 9.71 to $22.95 \mathrm{mg} / \mathrm{l}, 16.88$ to $28.85 \mathrm{mg} / \mathrm{l}$, and 20.66 to 43.59 $\mathrm{mg} / \mathrm{l}$ in summer, monsoon, and winter, respectively 
(Fig. 2). The average concentration of total nitrogen was $15.51 \mathrm{mg} / \mathrm{l}, 21.34 \mathrm{mg} / \mathrm{l}$, and $28.03 \mathrm{mg} / \mathrm{l}$ in summer, monsoon, and winter. The highest concentration was observed at sampling points SUL 5 and 6 and lowest at SUL 1 and 2 (Fig. $10 \mathrm{a}, \mathrm{b}, \mathrm{c}$ ). When precipitation is high during the monsoon, the hydrodynamic condition is increased, which reduces nutrient retention time, resulting in a decrease in total nitrogen concentration (Goedkoop and Petersson, 2000; Sun et al., 2009; Zhu et al., 2011). Seasonally the maximum concentration was observed in winter (43.59 $\mathrm{mg} / \mathrm{l})$ followed by monsoon $(28.85 \mathrm{mg} / \mathrm{l})$ and summer $(22.96 \mathrm{mg} / \mathrm{l})$. The increased concentration of total nitrogen is the result of domestic sewage discharge, agricultural runoff, and land-use change.

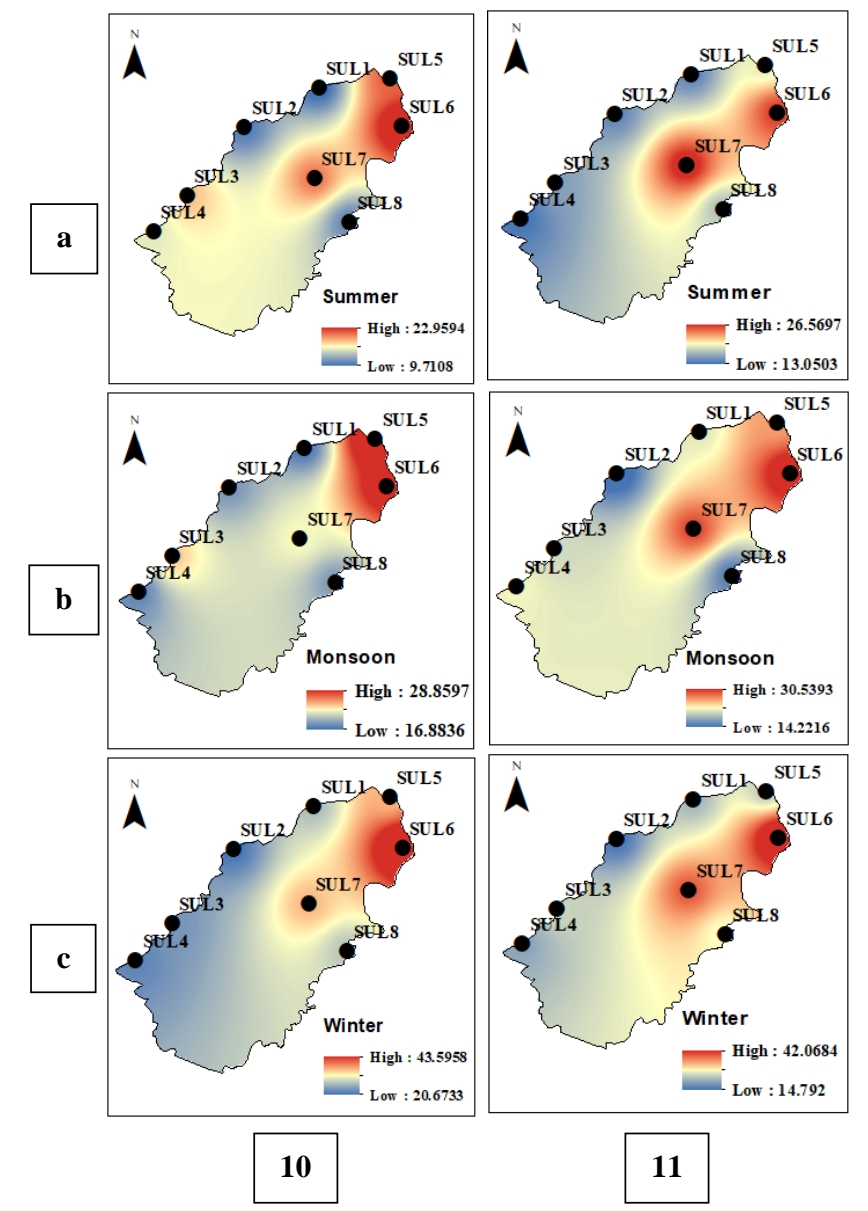

Fig 10a, b, c: shows spatial and seasonal variation of total nitrogen in 2017-18

11a, b, c: shows spatial and seasonal variation of total nitrogen in 2018-19
In 2018-19, the total nitrogen range was 13.05 to $26.57 \mathrm{mg} / \mathrm{l}, 14.22$ to $30.53 \mathrm{mg} / \mathrm{l}$, and 14.79 to 42.06 $\mathrm{mg} / \mathrm{l}$ in summer, monsoon, and winter, respectively (Fig. 3). The average value was $17.86 \mathrm{mg} / \mathrm{l}$ in summer, followed by $21.97 \mathrm{mg} / \mathrm{l}$ in monsoon and $25.11 \mathrm{mg} / \mathrm{l}$ in winter. The highest concentration was observed at sampling points SUL 6 and 7 and lowest at SUL 1 and 2 for all seasons (Fig. 11 a, b, c). Seasonally the maximum concentration was winter $(42.07 \mathrm{mg} / \mathrm{l})$ followed by monsoon (30.53 mg/l) and summer (26.57 $\mathrm{mg} / \mathrm{l})$. The maximum concentration was observed in winters due to the accumulation of nutrients in the absence of precipitation during the non-flood season. The yearly average shows that the total nitrogen concentration was almost similar for both years of sampling.

\section{Nitrite}

Nitrite is typically an intermediate product when ammonium is transformed into nitrate by microscopic organisms and is therefore seldom elevated in waters for long periods. It is also an intermediary product as nitrate transforms to nitrogen gas through denitrification (Wall, 2013). In 2017-18, the range of nitrite was 0.0039 to $0.054 \mathrm{mg} / \mathrm{l}, 0.0033$ to $0.0063 \mathrm{mg} / \mathrm{l}$ and 0.031 to $0.073 \mathrm{mg} / \mathrm{l}$ in summer, monsoon and winter, respectively (Fig. 2). The average value was $0.030 \mathrm{mg} / 1,0.0044 \mathrm{mg} / 1$ and $0.05 \mathrm{mg} / 1$ in summer, monsoon and winter respectively. Seasonally, the maximum concentration was observed in winter $(0.073 \mathrm{mg} / \mathrm{l})$ followed by monsoon $(0.0063 \mathrm{mg} / \mathrm{l})$ and summer $(0.0031 \mathrm{mg} / \mathrm{l})$. The highest concentration was observed at sampling points SUL 7 and 8 and lowest at SUL 1 and 2 in all the seasons (Fig. 12 a, b, c). 


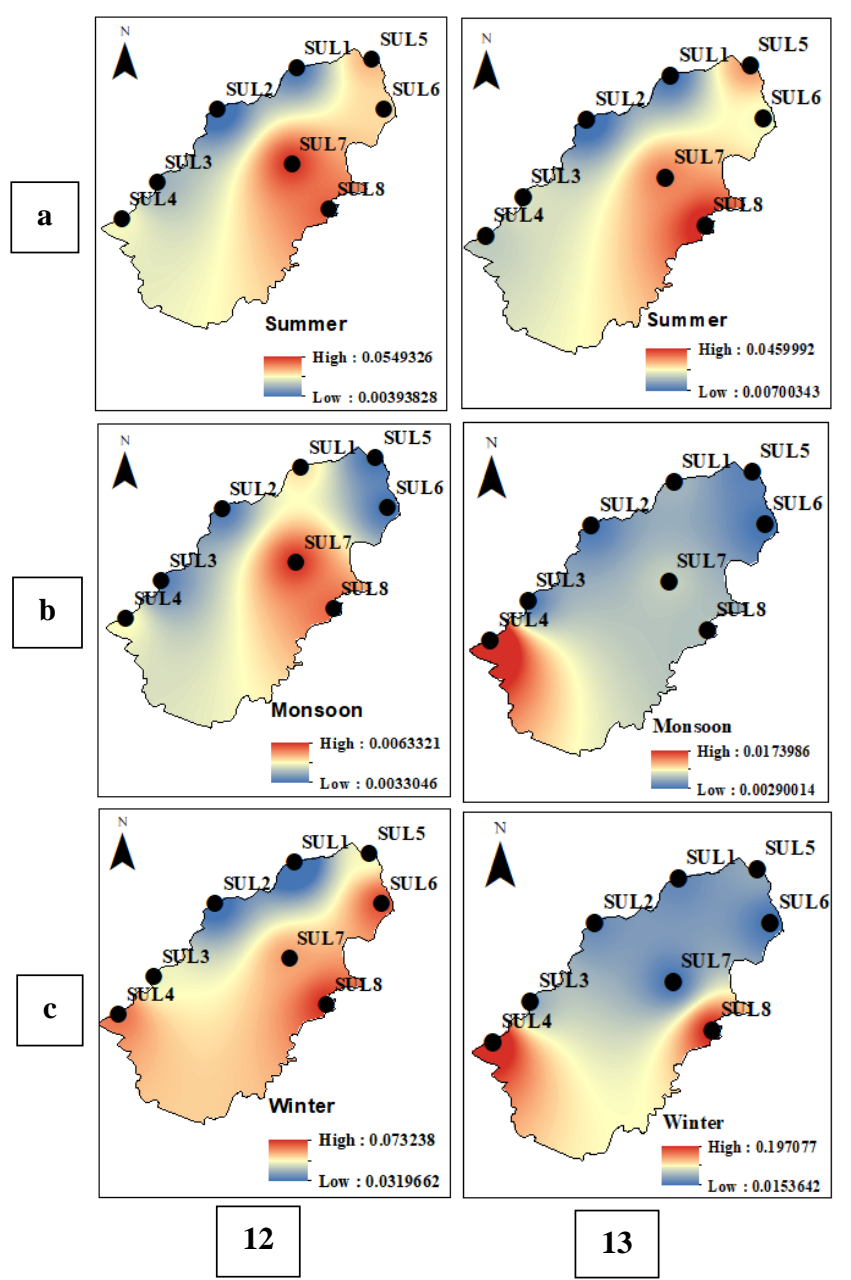

Fig 12a, b, c: shows spatial and seasonal variation of nitrite in 2017-18

13a, b, c: shows spatial and seasonal variation of nitrite in 2018-19

High nitrite concentration in the surface water shows a mechanism in which nitrogenous organic compounds oxidize into nitrate (Meng et al., 2018). In 2018-19, the range of nitrite was 0.0070 to $0.045 \mathrm{mg} / \mathrm{l}$, 0.0029 to $0.017 \mathrm{mg} / \mathrm{l}$, and 0.015 to $0.19 \mathrm{mg} / 1$ in summer, monsoon and winter respectively (Fig.3). The average value was $0.025 \mathrm{mg} / \mathrm{l}$ in summer, followed by $0.0058 \mathrm{mg} / \mathrm{l}$ in monsoon and $0.0068 \mathrm{mg} / \mathrm{l}$ in winter. The highest concentration was observed at sampling point SUL 8 and 4 and lowest at SUL 2, 6, and 7 for summer, monsoon, and winter respectively (Fig. 13 a, b, c). This is possibly due to livestock manure in and nearby the lake area (Meng et al., 2018). Seasonally, the maximum concentration in winter $(0.19 \mathrm{mg} / \mathrm{l})$ followed by summer $(0.045 \mathrm{mg} / \mathrm{l})$ and monsoon $(0.017 \mathrm{mg} / \mathrm{l})$. The yearly average shows that the concentration of nitrite was higher in 201819 as compared to 2017-18.

\section{Organic nitrogen}

In nature, organic nitrogen is directly transformed to the ammonium form followed by nitrite and nitrate. Dissolved organic nitrogen are generally found in lakes and streams as a product by photosynthetic organism, excretion by the animals, leachate from the soil and sewage discharge (Jørgensen, 2009; Wall 2013). In 2017-18, the range of organic nitrogen was 2.33 to $7.93 \mathrm{mg} / \mathrm{l}, 5.10$ to $15.25 \mathrm{mg} / \mathrm{l}$, and 5.66 to 10.40 $\mathrm{mg} / \mathrm{l}$ in summer, monsoon, and winter, respectively (Fig. 2). The average value was $4.99 \mathrm{mg} / \mathrm{l}, 8.93 \mathrm{mg} / \mathrm{l}$, and $8.19 \mathrm{mg} / \mathrm{l}$ in summer, monsoon, and winter. Seasonally the maximum concentration was observed in monsoon $(15.25 \mathrm{mg} / \mathrm{l})$ followed by winter (10.41 $\mathrm{mg} / \mathrm{l})$ and summer $(7.93 \mathrm{mg} / \mathrm{l})$. Generally, dissolved organic nitrogen is found to be higher in summer than winter because of the frequent release by algae and macrophytes (Jørgensen, 2009). But, in Sultanpur lake, due to continuous water pumping into the system, dilution of dissolved organic nitrogen occurs, which tends to lower the concentration. The highest concentration was observed at sampling points SUL 5 and 6 due to and lowest at SUL 1 and 4 in all the seasons (Fig. 14 a, b, c).

In 2018-19, the range of organic nitrogen was 2.88 to $10.16 \mathrm{mg} / \mathrm{l}, 2.89$ to $7.00 \mathrm{mg} / \mathrm{l}$ and 5.03 to $10.32 \mathrm{mg} / \mathrm{l}$ in summer monsoon and winter respectively (Fig. 3). The average value was $5.49 \mathrm{mg} / \mathrm{l}$ in summer, followed by $5.54 \mathrm{mg} / \mathrm{l}$ in monsoon and $7.54 \mathrm{mg} / \mathrm{l}$ in winter. The highest concentration was observed at sampling points SUL 5 and 6 and the lowest SUL 1 and 4 for all the seasons (Fig. $15 \mathrm{a}, \mathrm{b}, \mathrm{c})$. Summer $(10.16 \mathrm{mg} / \mathrm{l})$ and monsoon $(10.33 \mathrm{mg} / \mathrm{l})$ had almost equal concentration followed by monsoon $(7.00 \mathrm{mg} / \mathrm{l})$. The yearly average shows that the concentration of organic nitrogen was higher in 2017-18 as compared to 2018-19. 

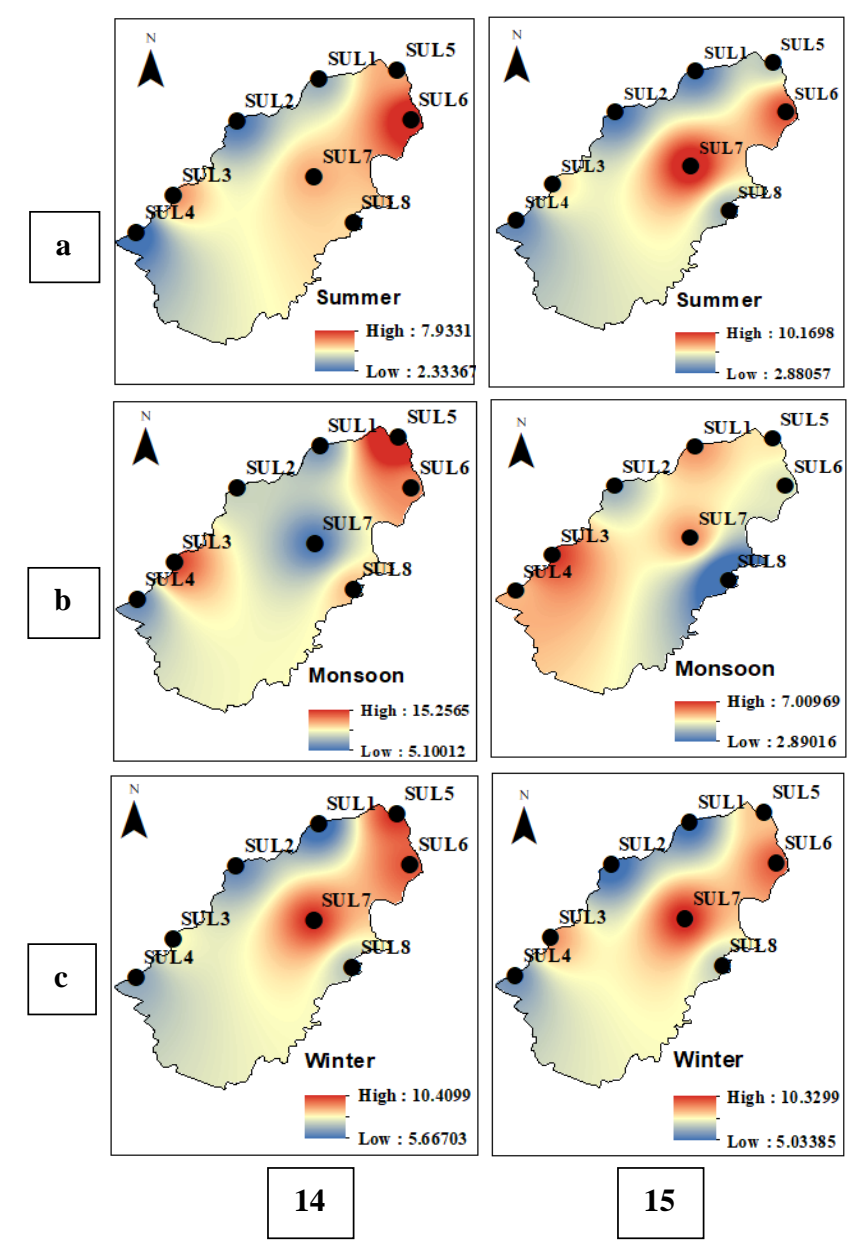

14a, b, c shows spatial and seasonal variation of organic nitrogen in 2017-18

$15 a, b, c$ shows spatial and seasonal variation of organic nitrogen in 2018-19

\section{IV.CONCLUSION}

Ammonia concentrations were discovered to be greater than categories D and A of CPCB and BIS IS: 10500 standards respectively whereas nitrate was within the standard limits. Standards for organic nitrogen, nitrite, and total nitrogen are not available in the Indian context. According to BIS and CPCB standards, levels exceeding $45 \mathrm{mg} / \mathrm{l}$ for nitrate and 1.2 $\mathrm{mg} / \mathrm{l}$ for ammonia in surface water can lead to human and health problems (Gupta et al., 2010; Prakasa Rao et al., 2017).

Human interventions are responsible for the increase in the reactive nitrogen concentration. Enrichment of nitrogenous species has a detrimental effect on the water quality of lakes, rivers, aquifers, and coastal water bodies, leading to the phenomenon of eutrophication (Rao and Puttanna, 2006). A notable seasonal variation characterized the average concentration of reactive nitrogen forms in the surface water of Sultanpur lake. The largest concentration was observed in the winter season and lowest in the summer season at the analyzed sampling points. The concentration of nitrate and ammonia indicated that the contamination concentration was mainly located near the points that are influenced by anthropogenic inputs of pollutants, the biochemical process of aquatic plants, and hydrodynamic conditions. Currently, the main factors influencing Sultanpur Lake are irrigation return flow and groundwater pumping. An important consideration which will help minimize reactive nitrogen losses into the environment is to keep applied and residual sources of nitrogen within the soil-crop system by curtailing transport processes (leaching, runoff, erosion, and gaseous losses) that carry nitrogen into the surrounding environment. With the increasing urbanizations and anthropogenic threats, it is necessary to frame and execute a management plan for the wetland and facilitate conservation efforts. Creating awareness among the local people regarding the importance of the wetland which plays a very crucial role in sustaining the local environment.

\section{ACKNOWLEDGMENTS}

The authors are grateful to Guru Gobind Singh Indraprastha University, Delhi for Short Term Research Fellowship and Faculty Research Grant Scheme for carrying out the entire study. We would also like to thank the Dean, University School of Environment Management, for technical and research support. The authors wish to convey their sincere gratitude to the people concerned for their help in fieldwork. 


\section{REFERENCES}

[1]. A. Sapek, 2008. Phosphate and ammonium concentrations in groundwater from peat soils in relation to the water table. Polish Journal of Soil Science 2(41): 139-148.

[2]. Abdel-Moati MAR, Beltagy AI, Mamoney M (1990) Nutrient balance and biomass productivity interrelations in the coastal lagoon Burullus, Egypt. Rapp comm Int Mer Medit 32(1): 69.

[3]. APHA (American Public Health Association), 2005. Standards methods for the examination of water and wastewater, 20th edition. American Public Health Association, Washington DC

[4]. Araújo, F.G., M.C. Costa de Azevedo \& M.D.N. Lima Ferreira, 2011. Seasonal changes and spatial variation in the water quality of a eutrophic tropical reservoir determined by the inflowing river. Lake and Reservoir Management 27(4): 343-354.

[5]. Banerjee. P. \& A. Pal, 2017. A note on Sultanpur National Park, the Bird Paradise of Haryana. In SCON ENVIS newsletter- Sarovar Saurabh, Ibrahim, M. N. M. Dr. K. Sankar 7:10

[6]. Brindha, K., R. Rajesh, R. Murugan \& L. Elango, 2012. Nitrate pollution in groundwater in some rural areas of Nalgonda district, Andhra Pradesh, India. Journal of environmental science \& engineering 54(1): 64-70.

[7]. Burrough, P.A., R. McDonnell, R. A. McDonnell \& C.D. Lloyd, 2015. Principles of geographical information systems. Oxford university press.

[8]. Central Pollution Control Board (CPCB) (1982) Surface water quality standards. Central Pollution Control Board. New Delhi, India. Available via http://ismenvis.nic.in/Database/Environmental_ Standards_7391.aspx Accessed on 20 Sep 2019
[9]. Czyzyk, F. \& M. Strzelczyk, 2008. Pollution of aquatic environment as an effect of slurry application on light and heavy soils. WaterEnvironment-Rural Areas 8(1): 61-68.

[10]. Devine, J.A. \& M.J. Vanni, 2002. Spatial and seasonal variation in nutrient excretion by benthic invertebrates in a eutrophic reservoir. Freshwater biology 47(6): 1107-1121.

[11]. Fleming, R. \& P.E.H. Fraser, 2001. The impact of waterfowl on water quality. Literature Review. Ontario: Ridge town College, University of Guelph.

[12]. Goedkoop W, Pettersson K (2000) Seasonal changes in sediment phosphorus forms in relation to sedimentation and benthic bacterial biomass in Lake Erken. Hydrobiologia 431(1): 41-50. https://doi.org/10.1007/s10933-0099403-y

[13]. Gupta, S., R.C. Gupta, A.B. Gupta, S. Eskiocak, E.V.S.P. Rao, K. Puttanna \& A. Singhvi, 2010. Pathophysiology of nitrate toxicity in human and its mitigation measures. Bull. Regional Assessment of Reactive Nitrogen 20: 1-78. https://www.pca.state.mn.us/sites/default/files/ wq-s6-26a.pdf

[14]. Huang, J., K.L. Jia, C.Y. Li, D.N. Zhu, W. Liang \& Luo, Q., 2010. Analysis of Hydrological Sequence Complexity and Trend Based on Wavelet De-noising [J]. Water Saving Irrigation 10: 40-42.

[15]. Jansson, M., L. Leonardson \& J. Fejes, 1994b. Denitrification and nitrogen retention in a farmland stream in southern Sweden. Ambio 23: 326-331.

[16]. Jørgensen, N. O. G. 2009. Organic nitrogen. Encyclopedia of inland waters 2: 832-851.

[17]. Kalpavriksh. 1994. Small and beautiful Sultanpur National Park. New Delhi.

[18]. Koc, J. \& K. Solarski, 2006. The effect of reclamation systems on washing nitrogen and phosphorus out of agriculturally used 
catchments. Water-Environment-Rural Areas 6(1): 195-205.

[19]. Krithika, K., R. Purvaja \& R. Ramesh, 2008. Fluxes of methane and nitrous oxide from an Indian mangrove. Current Science: 218-224. Lehtoranta, J., H. Pitkänen \& O. Sandman, 1997. Sediment accumulation of nutrients $(\mathrm{N}$, $\mathrm{P})$ in the eastern Gulf of Finland (Baltic Sea). Water, Air, and Soil Pollution 99(1): 477-486.

[20]. Li, X., J. Song, H. Yuan, J. Dai \& N. Li, 2007. Biogeochemical characteristics of nitrogen and phosphorus in Jiaozhou Bay sediments. Chinese Journal of Oceanology and Limnology 25(2): 157-165.

[21]. Manikannan, R., S. Asokan \& A.M.S. Ali, 2012. Abundance and factors affecting population characteristics of waders (Charadriiformes) in great vedaranyam swamp of point calimere wildlife sanctuary, south-east coast of India. International Journal of ecosystem, 2(1): 6-14.

[22]. Meng. Z, Y. Yang., Z. Qin \& L. Huang, 2018. Evaluating temporal and spatial variation in nitrogen sources along the lower reach of Fenhe River (Shanxi Province, China) using stable isotope and hydro chemical tracers. Water 10(3):

231.

10.1371/journal.pone.0098833

[23]. Moffat, A.S., 1998. Global nitrogen overload problem grows critical. Science 279: 988-989

[24]. Okbah, M.A. \& N.R. Hussein. 2006. Impact of environmental conditions on the phytoplankton structure in Mediterranean Sea Lagoon, Lake Burullus, Egypt. Water, air, and soil pollution 172(1-4): 129-150. https://doi.org/10.1007/s11270-005-9066-x

[25]. Prasanna, M.V., S. Chidambaram, T.V. Gireesh \& T.J. Ali, 2011. A study on hydro chemical characteristics of surface and sub-surface water in and around Perumal Lake, Cuddalore district, Tamil Nadu, South India. Environmental Earth Sciences, 63(1): 31-47.
[26]. Rahmani, A.R. \& M. Islam, 2004. Important bird areas in India. IBCN, Bombay Natural History Society.

[27]. Rahmani, A.R., M.Z. Islam \& R.M. Kasambe, 2016. Important bird and biodiversity areas in India: priority sites for conservation (revised and updated). Bombay Natural History Society, Indian Bird Conservation Network, Royal Society for the Protection of Birds and BirdLife International (UK), 1992.

[28]. Rajmohan N. \& L. Elango, 2005. Nutrient chemistry of groundwater in an intensively irrigated region of Southern India. Environmental Geology 47: 820-830.

[29]. Rao, E.P. \& K. Puttanna, 2006. Strategies for combating nitrate pollution. Current science 1335-1339.

[30]. Saunders, D. L. \& J. Kalff, 2001. Nitrogen retention in wetlands, lakes and rivers. Hydrobiologia 443(1): 205-212.

[31]. Singh, P., S. Javed, S. Shashtri, R.P. Singh, C.A. Vishwakarma, \& S. Mukherjee, 2017. Influence of changes in watershed landuse pattern on the wetland of Sultanpur National Park, Haryana using remote sensing techniques and hydrochemical analysis. Remote Sensing Applications: Society and Environment 7: 8492.

[32]. Siva T. \& P. Neelanarayan, 2017. Checklist of birds of Koothappar Big Tank in Tiruchirapalli District, Tamil Nadu. In SCON ENVIS newsletter- Sarovar Saurabh, Ibrahim, M. N. M. Dr. K. Sankar 1-6.

[33]. Smith, R.D., A. Ammann, C. Bartoldus, \& M.M. Brinson, 1995. An approach for assessing wetland functions using hydrogeomorphic classification, reference wetlands, and functional indices. army engineer waterways experiment station Vicksburg MS.

[34]. Stewart, R.E. 2001 Technical Aspects of Wetlands: Wetlands as Bird Habitat. National 
Water Summary on Wetland Resources, United States Geological Survey 86.

[35]. Sun, B., Li, C. Y., Yang, Z. Y., \& Zhu, D. N. 2009. Changes of Dissolved Oxygen and Analysis of the Impact Factor in Main Drainage Channel in the Hetao Irrigation District [J]. China Rural Water and Hydropower, 5, 68-75.

[36]. Syphard A. D. \& M.W. Garcia, 2001. Human and beaver induced wetland changes in the Chickahominy River watershed from 1953 to 1994. Wetlands, 21(3): 342-53.

[37]. Vitousek, P. M., J. D. Aber, R. W. Howarth, G. E. Likens, P. A. Matson, D. W. Schindler, W. H. Schlesinger \& D. G. Tilman, 1997. Human alteration of the global nitrogen cycle: sources and consequences. Ecological application 7: 737-750.

[38]. Wall, D. 2013. Nitrogen in Waters: Forms and Concerns. Nitrogen in Minnesota Surface Waters, Minnesota Pollution Control Agency. Accessed May, 25, 2019.

[39]. Weller, M.W. 1999. Wetland bird habitat resources and conservation implications. Press syndicate of the University of Cambridge, United Kingdom. 316.

[40]. Zhu D, Li C, Sun B et al (2011) Temporal and spatial distribution of total nitrogen, total phosphorus and COD in the largest shallow lake of the upper Yellow River. Paper presented at the International Symposium on Water Resource and Environmental Protection. Xi'an, Shannxi Province, China, 20-22 May 2011

\section{Cite this article as :}

Priyanka Verma, Pamposh, "Seasonal Changes and Spatial Variation of Reactive Nitrogen in Sultanpur Lake, Haryana, India", International Journal of Scientific Research in Science and Technology (IJSRST), Online ISSN : 2395-602X, Print ISSN : 2395-
6011, Volume 8 Issue 2, pp. 477-488, March-April 2021. Available at

doi : https://doi.org/10.32628/IJSRST218270

Journal URL : https://ijsrst.com/IJSRST218270 